\title{
Pedigree analysis on the population of Gir cattle in Northeast Brazil
}

\author{
Aracele Prates de Oliveira ${ }^{1}$, Carlos Henrique Mendes Malhado,6, Paulo Luiz Souza \\ Carneiro ${ }^{2}$, Raimundo Martins Filho ${ }^{3}$, Éderson Silva Silveira ${ }^{4}$, Laaina de Andrade Souza ${ }^{1}$, \\ Lorena Mirelle Santos Muniz ${ }^{4}$, Danielle Maria Machado Ribeiro Azevêdo ${ }^{5}$
}

\footnotetext{
${ }^{1}$ Doutoranda em Zootecnia, Universidade Estadual do Sudoeste da Bahia, Itapetinga, BA, Brasil.

2 Departamento de Ciências Biológicas, Universidade Estadual do Sudoeste da Bahia, Jequié, BA, Brasil.

3 Universidade Federal do Ceará, Cariri, CE, Brasil.

${ }^{4}$ Mestrando em Zootecnia, Universidade Estadual do Sudoeste da Bahia, Itapetinga, BA, Brasil.

${ }^{5}$ Empresa Brasileira de Pesquisa Agropecuária, Embrapa Meio-Norte.

${ }^{6}$ Scholar from CNPq.
}

\begin{abstract}
The objective of this study was to characterize the population genetic structure of the Gir breed in the Northeast of Brazil. The data used in this study were taken from pedigree information of 8,897 Gir animals between 1957 and 2007, obtained from the Brazilian Zebu Breeders Association (ABCZ). The program ENDOG was used to estimate the parameters based on the probability gene origin. From the amount of the studied animals, 67.22\%, 18.41\% and $3.15 \%$ had complete pedigree only on the first, second and third parentage, respectively. The number of ancestors that contributed for the reference population was 2,755, of which only 171 explain the $50 \%$ genetic variability of the population. The actual number of founder herds was 168 and the effective number of founder herds was 22.3. The number of sire supplier herds was 22.16, 8.66 and 5.36 for fathers, grandfathers and great-grandfathers, respectively. The average coefficient of relatedness was estimated at $0.22 \%$; the highest individual coefficient was $1.49 \%$. The little variability of the current population is a result of the small number of effective founders and ancestors indicating the population evolved from a narrow genetic base.
\end{abstract}

Key Words: ancestry, inbreeding, population structure

\section{Introduction}

Gir was one of the first breeds imported from India by the Brazilians. Historically, the first examples of the breed were introduced in Brazil around 1906. For some time it was the most numerous and valued Zebu breed in the country (Santiago, 1986).

The Herd-Book was implemented in Brazil in 1938 and by 2010, according to data from the Brazilian Association of Breeders of Zebu (ABCZ, 2010), 637.673 animals of the Gir breed were registered, corresponding to $6.6 \%$ of the records, only lower than Nelore (75.38\%) and Nelore Mocho (7.16\%) (ABCZ, 2010).

According to the statistical report of semen production, import and marketing by ASBIA (Brazilian Association of Artificial Insemination), 689,852 doses of semen of Gir were sold in 2010, occupying the first place in sales of dairy breeds, or $47.79 \%$ of the national market (ASBIA, 2010).

According to Cruz (2005) the structure of a population can be defined by the frequency of alleles that comprise the different genotypes of the individuals belonging to it. Pedigree information has been used to assess genetic diversity and structure of the Brazilian Zebu populations (Oliveira, 2009; Faria et al., 2001, 2009; Vercesi Filho et al., 2002; Malhado et al., 2008).

Within this context, this study aimed to characterize the population structure of Gir in northeastern Brazil, by determining the actual number of founders and ancestors, average coefficient of relatedness (AR), coefficient of inbreeding and number of equivalent generations.

\section{Material and Methods}

The data used were obtained from pedigree information of 8,897 animals of the Gir breed, from 1957 to 2007, from the Brazilian Association of Zebu Breeders (ABCZ).

The program ENDOG (Gutiérrez \& Goyache, 2005) was used for the pedigree analysis and estimation of the parameters based on the probability of origin of the gene, mean coefficient of inbreeding and the average coefficient of relatedness.

The estimation of the parameters based on the probability of origin of the gene, the actual number of founders and the actual number of ancestors were calculated. The actual 
number of founders represents the number of animals with equal contribution which would produce the same genetic variability found in the studied population. The classical approach in determining the actual number of founders was given by:

$f_{e}=\frac{1}{\sum_{k=1}^{f} q_{k}^{2}}$

in which: $f_{\mathrm{e}}=$ actual number of founders; $\mathrm{q}_{\mathrm{k}}=$ probability that the gene is originated from founder $k$.

The actual number of ancestors represents the minimum number of animals (founders or not) needed to explain the total genetic diversity of the population studied. The determination of the actual number of ancestors was made by computing the marginal contribution of each ancestor by:

$f_{a}=\frac{1}{\sum_{j=1}^{a} q_{j}^{2}}$

in which: $f_{a}=$ actual number of ancestors; $q_{j}=$ marginal contribution of an ancestor $j$ (not necessarily founder), i.e., the genetic contribution of ancestor that is not explained by a previously chosen ancestor.

For the calculation of the coefficient of inbreeding (F) the algorithm proposed by Meuwissen \& Luo (1992) was used.

The average coefficient of relatedness.(AR) or average relatedness coefficient (AR) simultaneously calculates the consanguinity and individual coancestrality (Gutiérrez et al., 2003). This parameter was calculated using an algorithm to obtain a c' vector defined as:

$c^{\prime}=(1 / n) 1^{\prime}$ A

in which: A is the numerator relationship matrix of $n \times n$ size.

On the other hand, the numerator relationship matrix may be obtained from the matrix $P$ where $P i j$ is equal to 1 if $j$ is the father of $i$ and 0 in case it is not, which defined the fathers of the animals (Quaas, 1976), by means of:

$A=(I-1 / 2 P)-1$ D (I - 1/2 P') -1

where $\mathrm{I}$ is the identity matrix and $\mathrm{D}$ is a diagonal matrix with non-zero elements obtained by:

dii $=1-1 / 4$ ajj - $1 / 4$ akk;

dii $=1$, if none of the fathers is known; dii $=3 / 4$, if one of the fathers is known; dii $=1 / 2$, if both parents are known; $j$ and $\mathrm{k}$ are the parents of individual $\mathrm{i}$.

From [2], $\quad$ A $\left(I-1 / 2 P^{\prime}\right)=(I-1 / 2 P)-1 D$

Pre-multiplying both sides of [3] by $(1 / \mathrm{n}) 1^{\prime}$ ' we get:

(1/n) $1^{\prime}$ A $\left(I-1 / 2 \mathrm{P}^{\prime}\right)=(1 / \mathrm{n}) 1^{\prime}(\mathrm{I}-1 / 2 \mathrm{P})-1 \mathrm{D}$

And using [1]: c' $\left(\mathrm{I}-1 / 2 \mathrm{P} \mathrm{P}^{\prime}\right)=(1 / \mathrm{n}) 1^{\prime}(\mathrm{I}-1 / 2 \mathrm{P})-1 \mathrm{D}$

Multiplying c' in brackets and isolating c': $c^{\prime}=(1 / n) 1^{\prime}(I-1 / 2 P)-1 D+1 / 2 c^{\prime} P^{\prime}$

The equivalent number of generations, in turn, was obtained by the sum of the terms $(1 / 2)^{\mathrm{n}}$ of all known ancestors, where $\mathrm{n}$ is the number of generations that separates the individual from each ancestor known (Maignel et al., 1996).

The main founders and/or ancestors were ordered in descending manner based on their values of AR and contribution, respectively, by the procedure SORT of SAS (Statistical Analysis System, version 9.1). For comparison purposes of classification of animals, in relation to AR and the contribution, a correlation analysis or sort order was performed using the Spearman correlation of PROC CORR of SAS (Statistical Analysis System, version 9.1).

\section{Results and Discussion}

Of the 8,897 studied animals, 67.22, 18.41, 3.15, 0.74 and $0.06 \%$ presented complete pedigree on the first, second, third, fourth and fifth ancestries, respectively. As the study went back in time, information on the ancestry of the animals was lost: $32.78 \%$ had no known parents; $81.59 \%$ had no known grandparents and $96.85 \%$ had no known greatgrandparents. These data are important in studies of population structure, since the precision of the estimates of the parameters depend on the quality and completeness of pedigrees. Pedigree with incomplete or erroneous information may underestimate endogamy, complicating its interpretation.

The reference population, in which both parents are known, contained only 5,945 animals; 2,952 animals presented unknown parents (Table 1 ). The actual number of ancestors $\left(f_{\mathrm{a}}\right)$ was 260 and the actual number of founders $\left(f_{\mathrm{e}}\right)$ was 286. Studying the genetic structure of Brazilian Zebu populations, Faria et al. (2009) recorded 211 and 284, respective actual number of founders and ancestors, in Gir.

Table 1 - Population parameters of Gir cattle in northeastern Brazil

Total population $\quad 8897$

Number of founders in the reference population 2870

Effective number of founders in the reference population 286

Number of founders with one or more parents unknown 2952

Equivalent number of founders

2916.5

(one unknown father = medium founder)

Number of animals in the reference population 5945

Number of ancestors in the reference population 2755

Effective number of ancestors in the reference population 260

Actual number of founder herds 168

Effective number of founder herds 22.3

Effective number of herds producing parents 22.16

Effective number of herds producing grandparents 8.65

Effective number of herds producing great-grandparents 5.36

Number of ancestors that explain $50 \%$ of the variability 171 
The ratio of $f_{\mathrm{e}} / f_{\mathrm{a}}$ observed in this study (1.1), which expresses the bottleneck effect, was lower than the value of 1.34 observed by Faria et al. (2009) analyzing the Gir population recorded at ABCZ and Reis Filho et al. (2010), who found a value of 1.95 analyzing the population of the Brazilian National Program for the Improvement of the Dairy Gir Cattle (PNMGL). The higher the value of the $f_{\mathrm{e}} / f_{\mathrm{a}}$ ratio, the higher the bottleneck effect resulting from the decrease of the number of reproducers over the generations. The longer the distance between $f_{\mathrm{a}}$ and $f_{\mathrm{e}}$, the shorter the participation of all founder animals in the population over the generations. Ideally, the actual number of founders is equal to the actual number of ancestors, or the difference between them is always the smallest possible (Albuquerque, 2010).

Only 2,755 ancestors contributed to the population, and only 171 explain $50 \%$ of the genetic variability of the population. This result indicates that $50 \%$ of the genes come from 171 ancestors. The most critical situation was found by Faria et al. (2009) for the Nelore and Guzerá breeds, where 55.58 and $41.06 \%$ of the genes came from only 50 ancestors, respectively. Malhado et al. (2008) found the values of 12.5, 25.0 and $50.0 \%$ for the Nelore breed in Bahia, explaining the genetic contribution of the 10, 50 and 414 most influential ancestors. For the breed Indubrasil, Vercesi Filho et al. (2002) found 10 and 50 ancestors responding for 23.47 and $50.58 \%$ of the genes of the population under study.

The actual number of founding herds was 168 and the effective number of founding herds was only 22.3. The number of herds that provided breeder animals was 22.16, 8.65 and 5.36 for parents, grandparents and greatgrandparents, respectively. Few herds providing breeders may contribute to the increase of endogamy in the population due to the intensive use of breeders.

Founders are animals that contribute to the formation of the herd, but have no pedigree identified. The most important founder to the herd was the male 312.275, with AR $1.25 \%$ (Table 2). Only one female (849.279) was found among the tem main founders. Of the ten animals identified as founders, eight were also classified as ancestors. This association can be verified through the Spearman correlation. The Spearman correlation between the classification of the 171 founder animals, by AR, and ancestors, by the contribution, was $95.05 \%(\mathrm{P}<0.01)$, indicating that most founders are also ancestors, showing a slight bottleneck effect. The ancestor of most relevance was the male 378,474, which was responsible for 2.77 of the genetic variability of the population.

The average coefficient of inbreeding $(F)$ to the inbred animals was 11.09. The highest value of $\mathrm{F}$ between individuals of the population was 28.12, obtained from only two animals; 132 animals presented value equal to 25 . The coefficient of inbreeding ( $F$ ) was equal to zero from 1957 to 1987, with exception of 1984 (0.036\%). It should be noted that this period includes animals without known ancestry, regarded as non-inbred animals and therefore with $\mathrm{F}$ equal to zero. From 1988 to 2001, F values lower than 1\%, with maximum value of $0.84 \%$ in 1992 (Figure 1 ) were found.

Table 2 - Description of the ten main founders and ancestors that explain the genetic variability of the population of Gir

\begin{tabular}{|c|c|c|c|c|c|c|}
\hline Founder & Father & Mother & Gender & Year of birth & AR (\%) & $\mathrm{N}^{\circ}$. of calves/breeder animals \\
\hline 312275 & & & M & 1977 & 1.25 & 23 \\
\hline 1879832 & & & M & 1975 & 1.20 & 49 \\
\hline 1574071 & & & M & 1971 & 1.07 & 91 \\
\hline 576812 & & & M & 1983 & 1.07 & 106 \\
\hline 861795 & & & $\mathrm{M}$ & 1978 & 0.95 & 79 \\
\hline 1957481 & & & $\mathrm{M}$ & 1975 & 0.95 & 165 \\
\hline 1882954 & & & M & 1976 & 0.95 & 164 \\
\hline 849279 & & & $\mathrm{~F}$ & 1970 & 0.94 & 1 \\
\hline 368152 & & & M & 1987 & 0.76 & 112 \\
\hline 1992025 & & & M & 1966 & 0.67 & 99 \\
\hline Ancestor & Father & Mother & Gender & Year of birth & Contribution (\%) & $\mathrm{N}^{\circ}$. of calves/breeder animals \\
\hline 378474 & 312275 & 849279 & M & 1981 & 2.77 & 202 \\
\hline 1879832 & & & M & 1975 & 1.75 & 49 \\
\hline 1574071 & & & M & 1971 & 1.59 & 91 \\
\hline 576812 & & & $\mathrm{M}$ & 1983 & 1.57 & 106 \\
\hline 861795 & & & M & 1978 & 1.41 & 79 \\
\hline 1882954 & & & M & 1976 & 1.40 & 164 \\
\hline 1957481 & & & M & 1975 & 1.40 & 165 \\
\hline 368152 & & & M & 1987 & 1.10 & 112 \\
\hline 1992025 & & & M & 1966 & 0.99 & 99 \\
\hline 485026 & 377108 & 484935 & M & 1988 & 0.95 & 130 \\
\hline
\end{tabular}

F - female; M - male 


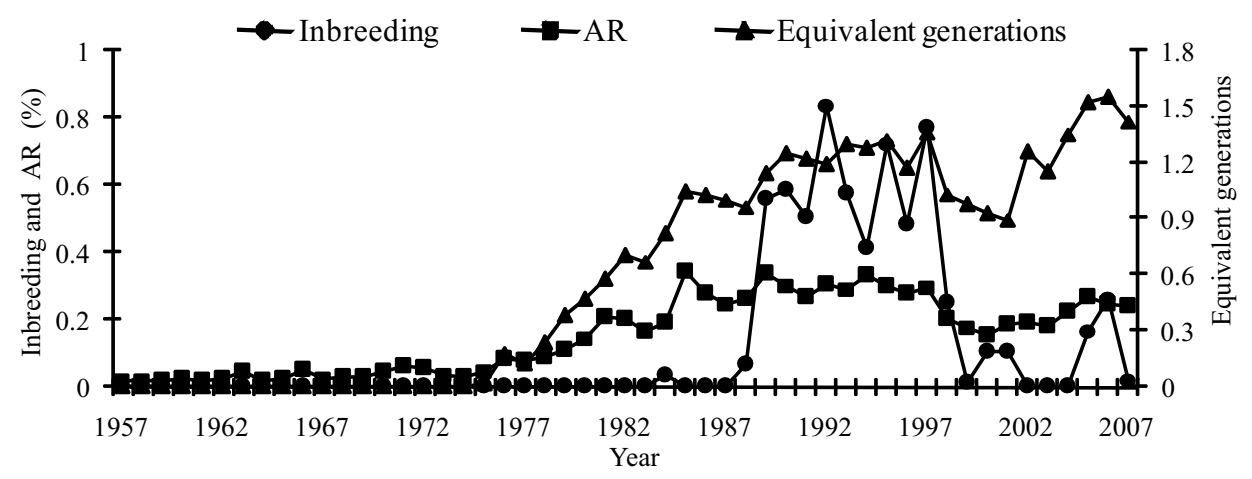

Figure 1 - Variation of inbreeding and average relatedness coefficient (AR), both in percentage, and average values of equivalent generations in Gir animals in northeastern Brazil.

The average coefficient of relatedness (AR) was estimated at $0.22 \%$; the highest individual coefficient was $1.49 \%$. The correlation coefficient presented values lower than $1 \%$ in the study period and reached the maximum value of $0.34 \%$ in 1985 and 1989 (Figure 1). The use of animals with lower AR values in matings will allow greater participation of animals little used in the herd, contributing to decreasing endogamy and avoiding possible losses of genetic material (Barros et al., 2011).

As the number of known generations increased, inbreeding and the average correlation coefficient also did. This relationship is most evident from 1985, period in which the average correlation coefficient and the number of equivalent generations had strong growth. The equivalent number of generations is represented by the number of generations that separate the individual from each ancestor known. For this reason, the greater the number of known ancestors, the greater the probability of obtaining high rates of endogamy. According to Queiroz et al. (2000), the better knowledge and control of genealogy with the passing of generations allows more accurate calculation of $\mathrm{F}$ and $\mathrm{AR}$, increasing their values.

\section{Conclusions}

The little variability of the current population results from the small number of founders and ancestors, indicating that the population has developed from a narrow genetic base. The low values recorded for the coefficients of inbreeding and correlation, at the beginning and end of the period evaluated, may be underestimated by the small amount of pedigree information, or reduced, depending on the control of the matings.

\section{References}

ASSOCIATION OF BREEDERS OF ZEBU- ABCZ [2010]. Available at: <http:// www.abcz.org.br> Accessed on: Dec. 18, 2010.

ALBUQUERQUE, A.L.S. Estrutura populacional de um rebanho leiteiro da raça Pardo-Suíça no estado do Ceará. 2010. 48f. Dissertação (Mestrado em Zootecnia) - Universidade Federal do Ceará, Fortaleza.

ASSOCIAÇÃO BRASILEIRA DE INSEMINAÇÃO ARTIFICIAL ASBIA. [2010]. Relatório Anual 1998. São Paulo. Available at: <http://www.asbia.org.br> Accessed on: Dec. 18, 2010.

BARROS, E.A.; RIBEIRO, M.N.; ALMEIDA, M.J.O. et al. Estrutura populacional e variabilidade genética da raça caprina Marota. Archivos de Zootecnia, v.60, p.1-10, 2011.

CRUZ, C.D. Princípios da genética quantitativa. Viçosa, MG: UFV, 2005. 394p.

FARIA, F.J.C.; VERCESI FILHO, A.E.; MADALENA F.E. et al. Parâmetros populacionais do rebanho Gir Mocho registrado no Brasil. Revista Brasileira de Zootecnia, v.30, n.6, p.1984-1988, 2001 (supl.).

FARIA, F.J.C.; VERCESI FILHO, A.E.; MADALENA F.E. et al, Pedigree analysis in the Brazilian Zebu breeds. Journal of Animal Breeding and Genetics, v.126, p.148-153, 2009.

GUTIÉRREZ, J.P.; ALTARRIBA, J.; DÍAZ, C. et al. Pedigree analysis of eight Spanish beef cattle breeds. Genetic Selection Evolution, v.35, p.43-64, 2003.

GUTIERREZ, J.P.; GOYACHE, F. A note on ENDOG: a computer program for analysing pedigree information. Journal of Animal Breeding and Genetics, v.122, p.172-176, 2005.

MAIGNEL, L.; BOICHARD, D.; VERRIER, E. Genetic variability of french dairy breeds estimated from pedigree information. Interbull Bull, v.14, p.49-54, 1996.

MALHADO, C.H.M.; CARNEIRO, P.L.S.; PEREIRA, D.G. et al. Progresso genético e estrutura populacional do rebanho Nelore no estado da Bahia. Pesquisa Agropecuária Brasileira, v.43, p.1163-1169, 2008

MEUWISSEN, T.H.E.; LUO, Z. Computing inbreeding coefficients in large populations. Genetics Selection Evolution, v.24, p.305-313,1992.

OLIVEIRA, P.S. Estrutura populacional e tendência genética de características de crescimento e adaptação da raça Nelore, linhagem Lemgruber. 2009. 96f. Dissertação (Mestrado em Zootecnia) - Faculdade de Zootecnia e Engenharia de Alimentos da Universidade de São Paulo, São Paulo.

QUAAS, R.L. Computing the diagonal elements and inverse of a large numerator relationship matrix. Biometrics, v.32, n.12, p.949-53, 1976. 
QUEIROZ, S.A.; ALBUQUERQUE, L.G.; LANZONI, N.A. et al. Efeito da endogamia sobre características de crescimento de bovinos da raça Gir no Brasil. Revista Brasileira de Zootecnia, v.29, n.4, p.1014-1019, 2000.

REIS FILHO, J.C.; LOPES, P.S.; VERNEQUE, R.S. et al. Population structure of Brazilian Gyr dairy cattle. Revista Brasileira de Zootecnia, v.39, n.12, p.2640-2645, 2010.
SANTIAGO, A.A. O Zebu na India, no Brasil e no mundo. Campinas: Instituto Campineiro de Ensino Agrícola, 1986. 745p.

VERCESI FILHO, A.E.; FARIA, F.J.C.; MADALENA, F.E. et al. Estrutura populacional do rebanho Indubrasil registrado no Brasil. Archivos Latinoamericanos de Produccíon Animal, v.10, n.2, p.86-92, 2002. 